\begin{tabular}{cc|c}
\hline Tar. Bil. Der. & Journal of Agricultural Sciences \\
& $\begin{array}{c}\text { Dergi web sayfası: } \\
\text { www.agri.ankara.edu.tr/dergi }\end{array}$ & Journal homepage: \\
& www.agri.ankara.edu.tr/journal
\end{tabular}

\title{
Determining of Risk Sources and Risk Management Strategies in Dairy Farms: A Case of Çanakkale Province
}

\author{
Damla ÖZSAYIN ${ }^{a}$ \\ ${ }^{a}$ Department of Organic Farming Business Management, Gökçeada Applied Sciences School, Çanakkale Onsekiz Mart University, Çanakkale, \\ TURKEY
}

\section{ARTICLE INFO}

Research Article

DOI: 10.15832 /ankutbd.405335

Corresponding Author: Damla ÖZSAYIN, E-mail: dozsayin@comu.edu.tr, Tel: +90 (286) 8872302

Received: 13 March 2018, Received in Revised Form: 19 May 2018, Accepted: 03 July 2018

\begin{abstract}
This study was aimed to determine farmers' risk sources and risk management strategies in dairy cattle farms in Çanakkale Province. Data were obtained from 302 farms selected by stratified random sampling method from dairy farms in Biga and Çan districts of Çanakkale province in Turkey between May 2017 and September 2017. Descriptive statistics and factor analysis were used to analyze the data. The results of this study show that the most important risk source for farmers was lack of credit availability. This risk was followed by inadequacy of artificial insemination and increase in debt amount. Parasite control was the most important risk management for farmers. This was followed by off-farm work, off-farm investment and on-farm measures. As a solution to the lack of credit availability, it should be provided to ease of repayment in credit use and to inceasing opportunities to loan use with low interest rate of farmers. In terms of parasite control in farms, it is important to the use of regularly parasitic drugs and determining of an effective parasite control program. As a result, it is expected to contribute to farmers and agricultural policy makers of the findings of this research.
\end{abstract}

Keywords: Cattle; Factor analysis; Off-farm work; Artificial insemination

(C) Ankara Üniversitesi Ziraat Fakültesi

\section{Introduction}

Agricultural sector is exposed to various risks from production to marketing depending on problems resulted from nature of agriculture (Akçaöz et al 2009). These risks can have negative effects on crop and livestock, and so farmers don't estimate their own income and yield because of some risks that can't be controlled and predicted (Hall et al 2003; Hazneci \& Ceyhan 2011). For this reason, farmers are obliged to take precautions against various risks. Furthermore, livestock is one of the sectors that plays a significant role in socioeconomic development of the region and in people's nutrition. Therefore, there is needed improvement of this sector for fulfill the increasing demands in animal food products and to increase farmers' income living in rural area (Bishu et al 2016). Thus, it can be said that practices that will be performed to assessment of farmers' risk behaviours and determining of risks negatively affecting agricultural production are important in terms of production planning. There is an extensive literature that are investigating farmers' 
attitudes and behaviors concerning risk sources and its management strategies in farms (Bosch \& Johnson 1992; Huirne et al 2000; Meuwissen et al 2001; Flaten et al 2005; Çukur et al 2011; Zhou et al 2012; Bishu et al 2016). However, in Turkey, there exists limited literature on this topic (Özsayın \& Çetin 2004; Akçaöz et al 2009; Hazneci \& Ceyhan 2011; Hayran \& Gül 2015). In Turkey, the number of total bovine animal was about 14 million head in 2016. It is about 205.855 head in Çanakkale province which has an important potential in terms of used technology and milk yield (Turkstat 2016). It constitutes about $1.5 \%$ of total bovine animal and $2.9 \%$ of total milk production in Turkey. Out of total milk production about $88.0 \%$ is provided from dairy cattle. The main reason for selecting of Biga and Çan districts of Çanakkale province as research area is to be milk production activities of the source of income for the great majority of agricultural farms in these districts. Besides, it hasn't reached to any study that was previously conducted to determine farmers' risk sources and risk management strategies in research area. Therefore, it is necessary to identification of risks encountered in farms and to determining of strategies to be taken against these risks in order to reach to expected income levels by making the right decision of farmers in research area. The objective of this study was to evaluate farmers' risks and risk management strategies in Biga and Çan districts of Çanakkale province. This study is expected to contribute to development of dairy farming activities in research area and to other studies in this topic, also.

\section{Material and Methods}

To estimate risk sources of farmers and management strategies, the data was obtained by survey using face to face interview technique from farms in Biga and Çan districts that have the highest number of dairy cattle in Çanakkale province between May 2017 and September 2017. These districts are constituted $42 \%$ of total dairy farms in Çanakkale province. The stratified random sampling method was used in study and the sample size was determined by Neyman Method (Yamane 1967). $n=\frac{\left(\sum N_{h} S_{h}\right)^{2}}{N^{2} D^{2}+\sum N_{h} S_{h}^{2}} \quad D^{2}=\frac{d^{2}}{z^{2}}$

$n$ is the sample size (302 farms), $N$ is the number of farm in districts (7112 farms), $N_{h}$ is the number of farm in the h stratum; the standard deviation for the h stratum is $S_{h}$, the variance for h stratum is $S_{h}^{2}, d$ is desired absolute precision, $z$ is desired confidence level (1.96 for 95\%), $D$ is acceptable error limit in mean. Thus, the sampling size was formed by farms selected randomly from these strata by dividing into strata with regards to the number of dairy cattle to farms in these districts. Farms were categorized as 3 to $\leq 11$ cattle (103 farms), 12 to $\leq 21$ cattle ( 72 farms) and equal 22 and $>21$ cattle (127 farms). All farms were evaluated together because there weren't important differences between strata of farms. Farmers' socio-economic characteristics was determined by descriptive statistics. In order to rank the importance of each risk and strategies, it was asked questions to farmers by using 5-point likert-type scale with a range from 1 (not important) to 5 (very important) (Çukur et al 2011; Ağır et al 2015). Factor analysis was used in order to determine to farmers' risk sources and risk management strategies in dairy cattle farms. Factor analysis is multivariate statistical technique used to analyze interrelationships among a large number of variables and to explaine variables in terms of common underlying dimensions. The factors are simply a weighted sum of the observed variables that the weights regarding to the variables differ from each other. Factors are interpreted by their factor loadings. It was categorised factor loadings by using another rule of thumb as \pm 0.30 minimal, \pm 0.40 important, and \pm 0.50 rather important (Hair et al 1995; Ağır et al 2015; Hayran \& Gül 2015). Therefore, factors were explicated for factor loadings greater than \pm 0.40 in this study. To measure the internal reliability and consistency of given responses to questions including ranked responses, it was calculated Cronbach's alpha $(\alpha \geq 0.7)$. The Kaiser Meyer Olkin $(\mathrm{KMO} \geq 0.6)$ and Barlett's test of Spherincity statistics $(\mathrm{P}<0.01)$ were calculated in order to test to suitability for factor analysis of the 
data (Hair et al 1995). The data were analyzed by using SPSS statistical analysis programme (SPSS 2008).

\section{Results and Discussion}

\subsection{Farmers'general characteristics}

The average household size was determined as 3.2 person in farms (Table 1). This size at national level is about 3.5 person (Turkstat 2016). Thus, this value is below the average household size at national level. Farmers' the average age and their dairy farming experience were determined 45.2 years and 20.3 years, respectively. The highest education level was primary school. The majority of farmers $(67.8 \%)$ had primary education and $16.4 \%$ of the farmers had the highest income $(\geq € 5432.1)$.

\subsection{Perception of risk sources in dairy cattle farms}

The sixteen risk sources were determined for farmers (Table 2), and the most important risk source with the highest mean was lack of credit availability. One possible reason of this result is their considerations about financial incapability of farmers in research area. This was followed by inadequacy of artificial insemination use, increase in debt amount, injury, illness and death of operator, inability to use modern technologies, lack of technical knowledge, lack of harmonisation to hygiene rules, decrease in the number of dairy cattle, and adverse weather conditions, respectively. Hall et al (2003) reported that risk sources were severe drought, cattle price variability and weather, and disease. In another study, these risks were determined as volatility in feed and milk price, production diseases, and misuse

Table 1- Farmers' some socio-economic characteristics

\begin{tabular}{lrrrr}
\hline Characteristics & 5-11 cattle & 12-21 cattle & $\geq 22$ cattle & Mean \\
\hline Age (year) & 44.3 & 47.1 & 45.6 & 45.2 \\
Education level (\%) & & & & \\
- Primary school & 70.0 & 68.7 & 66.0 & 67.8 \\
- Secondary school & 17.4 & 18.8 & 19.3 & 18.6 \\
- High school & 7.9 & 9.4 & 12.5 & 10.3 \\
- University & 4.7 & 3.1 & 2.2 & 3.3 \\
Household size (person) & 2.8 & 3.4 & 3.6 & 3.2 \\
Farmers' dairy farming experience (year) & 22.3 & 23.9 & 17.6 & 20.3 \\
"Household income (€ year $\left.{ }^{-1}\right)(\%)$ & & & & \\
$\leq € 2716.1$ & 44.4 & 28.1 & 19.3 & 29.5 \\
$€ 2716.2-€ 5431.8$ & 52.4 & 62.5 & 52.3 & 54.1 \\
$\geq € 5432.1$ & 3.2 & 9.4 & 28.4 & 16.4 \\
\hline
\end{tabular}

*, 1 Euro $=4.05$ TRY (Turkish lira) in June 2017

of drugs (Hayran \& Gül 2015). The sixteen items were distributed among six factors by factor analysis. KMO, Barlett's test and Cronbach's alpha values were calculated as $0.765,598.34$ and 0.769, respectively. These results supported to use of the factor analysis for risk sources. The six factors from 1 to 6 were labeled as production loss, institutional, disease, financial, technological and price, respectively. These factors explained $64.67 \%$ of total variance. Risk factors were determined as change in farming situation, legislation, production, and financial situation by Meuwissen et al (2001). In another study, these factors were defined as technology and cost, political and economics, land value and insurance (Hayran \& Gül 2015). Factor 1, production loss, had high loadings decrease in milk yield, injury, illness and death of operator, decrease in the number of dairy cattle and inadequacy of artificial insemination use. There are positive relationship between Factor 1 and their risk sources. The decrease in milk yield is an important criterion for production, and this risk has negative effects on 
production. This result was supported by findings of study conducted by Schaper et al (2009). Thus, it is expected to decrease of milk yield in farms due to problems negatively affecting milk yield such as death, disease of animals. Hence, farmers face with production losses. Another risk for farmers is operator's injury, illness, and death. It is important to keep healthy of farmer for continuity of production activities in farms. Because, various production losses come to exist in case such as injury and death of operator. These results were supported by findings of study conducted by Akçaöz et al (2009). The decrease in the number of animal is an important risk in milk production. The number of animal in farms decreases in the event of obligatory slaughtering, death, and disease, and so the quantity of milk production may change. Therefore, production losses can occur in farms. Similar results were reported in study conducted by Akçaöz et al (2009). Artificial insemination has important effects on accelerating animal breeding (Ferraz et al 2012). Hence, the inadequacy of artificial insemination use can affect adversely milk production. That is, it can cause to important losses in milk production when artificial insemination isn't successful in farms. Therefore, it is important to increasing of farmers' success in implementing artificial insemination and to the number of animal applied artificial insemination in order to decrease production loss. These results were supported by findings of study conducted by Akçaöz et al (2009). Factor 2, institutional, had high loadings increase in interest rates, inadequacy of agriculture and livestock supports, increase in input costs. There are positive relationship between Factor 2 and their risk sources. The increase in interest rates is important risk for farmer. Similar result was reported in study conducted by Akçaöz et al (2009). Thus, feed prices may increase depending on the increase in interest rates. The changes in feed prices cause a considerable increase in milk production cost of farms that don't make enough forage crops production. Hence, the profitability of farms decrease depending on the fall in milk prices. Therefore, the institutional regulations need in decreasing of risks related to interest rates. Livestock supports are more important for sustainable dairy farming. However, these supports haven't direct effect on farm income. They have positive effects on farmers' costs in preproduction and on their income in postproduction. Therefore, there is a need to increasing of livestock supports in order to decrease to income and production losses of their arising from various risks of farmers. Feed costs account for about $60-$ $70 \%$ of the all expenses in farms (Turan \& Altuner 2014). Thus, it is expected to increasing milk production costs of the increases in input prices forming production costs of farms. Factor 3, disease, had high loadings lack of harmonisation to hygiene rules, livestock diseases, increase in veterinary and drug prices. There are positive relationship between Factor 3 and their risk sources. Lack of harmonisation to hygiene rules is one of important risk for farms (Akçaöz et al 2009). Because, the animals in farms face with various diseases due to emergent microbial contamination depending on lack of hygiene and deficiency of other health protection precautions (Noordhuizen \& Cannas 2014). As a result of this, production of milk and its quality may decrease. Therefore, farmers about hygiene rules by institutions given animal health protection service in research area should inform, and the increasing of their harmonisation to hygiene rules in their own farms should provide, also. Furthermore, the increases in drug and veterinary prices cause to disregarding to the health of own animals of low-income farmers and not sufficiently benefiting from the advantages of animal health protection services. Factor 4, financial, had high loadings lack of credit availability and increase in debt amount. There are positive relationship between Factor 4 and their risk sources. This result are similar with the findings of Flaten et al (2005), which indicated that there was positive relationship between credit availability risk and credit factor. Dairy farming as in other business are also desired to be high of the working capital amount. Because, there is a need to adequate working capital to reach more rational working conditions and to reach targeted income level by increasing labor productivity. Therefore, farmers tend towards borrow from their external resources in order to meet own financial needs due to financial inadequacy and indebtness situation in farms. Hence, financing and 
debt situation of farms have great importance in terms of continuity of production activities and improvement. Therefore, it should provide to ease of repayment in credit use and to inceasing the use of loan with low interest rate of farmers. Furthermore, it can be expected to decreasing of the debt amount in farms by diversification of product and increasing of quantity of off-farm income. Factor 5, technological, had high loadings lack of technical knowledge and inability to use modern technology. There are positive relationship between Factor 5 and their risk sources. In farm, development of technical knowledge and modern technology need in terms of the productivity and sustainability. However, it is not easy to use of modern technologies and to adoption of their agricultural innovations by farmers due to inadequate financial power of farmers (Thornton 2010). Hence, they prefer to conventional livestock techniques due to problems such as lack of technical and up-to-date information and their difficulties in adaptation to modern technology. Due to these problems, it can be said that the development of dairy farming is affected negatively. Factor 6, price, had high loadings decrease in milk price and adverse weather conditions. There are positive relationship between Factor 6 and their risk sources. The high input costs and low milk prices have an important impact on farm. Because, the decrease in milk prices in spite of increase in input costs cause to decreasing of profit margin between product and input prices. Also, adverse weather conditions have important effects on the livestock sector and animal products (Akçaöz et al 2009; Thornton 2010). These risks affect negatively to total annual profit of farms. Hence, it is rather important to protection of dairy animals as far as possible from adverse weather conditions and their consequences. These results concerning risk sources show that all factors have negative effects on sustainability of dairy farming activity in research area. Therefore, it is necessary to take necessary precautions to reduce or eliminate to these risks.

Table 2- Mean and factor analysis results for risk sources

\begin{tabular}{lcrrrrrrr}
\hline \multirow{2}{*}{ Risk sources } & Mean & \\
& $(n=302)$ & $S D^{b}$ & \multicolumn{5}{c}{ Important factors $^{c}$} \\
\cline { 5 - 9 } & & & $F_{1}$ & $F_{2}$ & $F_{3}$ & $F_{4}$ & $F_{5}$ & $F_{6}$ \\
\hline Lack of credit availability & 4.65 & 0.63 & 0.186 & -0.004 & 0.037 & 0.783 & -0.147 & 0.160 \\
Inadequacy of artificial insemination use & 4.51 & 0.59 & 0.492 & 0.165 & 0.146 & 0.116 & 0.253 & 0.327 \\
Increase in debt amount & 4.48 & 0.75 & -0.040 & 0.261 & 0.097 & 0.754 & 0.261 & -0.011 \\
Injury, illness and death of operator & 4.38 & 0.55 & 0.703 & -0.077 & 0.112 & 0.316 & 0.282 & -0.094 \\
Inability to use modern technologies & 4.27 & 0.69 & 0.305 & -0.072 & 0.274 & 0.136 & 0.698 & -0.219 \\
Lack of technical knowledge & 4.26 & 0.64 & 0.036 & 0.291 & -0.091 & -0.053 & 0.704 & 0.252 \\
Lack of harmonisation to hygiene rules & 4.09 & 0.76 & 0.050 & -0.259 & 0.774 & 0.073 & 0.074 & 0.160 \\
Decrease in the number of dairy cattle & 4.08 & 0.65 & 0.627 & 0.118 & 0.164 & 0.026 & 0.229 & 0.173 \\
Adverse weather conditions & 4.05 & 0.86 & -0.146 & 0.062 & 0.150 & 0.324 & -0.016 & 0.618 \\
Livestock diseases (epidemic/non-epidemic) & 3.98 & 0.74 & 0.205 & 0.304 & 0.716 & 0.093 & -0.098 & -0.024 \\
Increase in input costs (e.g., feed) & 3.94 & 0.70 & 0.138 & 0.649 & 0.335 & -0.192 & -0.011 & 0.280 \\
Increase in interest rates & 3.88 & 0.69 & 0.056 & 0.783 & 0.108 & 0.169 & 0.124 & 0.131 \\
Decrease in milk price & 3.80 & 0.65 & 0.335 & 0.013 & 0.041 & -0.066 & 0.067 & 0.713 \\
Decrease in milk yield & 3.79 & 0.75 & 0.779 & 0.166 & 0.021 & -0.095 & -0.195 & -0.006 \\
Inadequacy of agriculture and livestock supports & 3.69 & 0.62 & 0.156 & 0.662 & -0.104 & 0.243 & 0.097 & -0.285 \\
Increase in veterinary and drug prices & 3.65 & 0.75 & 0.098 & 0.386 & 0.668 & 0.017 & 0.212 & 0.101 \\
Percent of the variance explained (\%) & & & 13.13 & 25.73 & 37.43 & 47.27 & 55.99 & 64.67 \\
\hline
\end{tabular}

a,b, mean and standard deviation (SD) (1, not important; 5 , very important); c, factors 1 to 6 are labelled as $\mathrm{F}_{1}$, production risk; $\mathrm{F}_{2}$, institutional risk; $\mathrm{F}_{3}$, disease risk; $\mathrm{F}_{4}$, financial risk; $\mathrm{F}_{5}$, technological risk and $\mathrm{F}_{6}$, price risk; Factor loadings for value greater than 0.4 are in bold 


\subsection{Risk managemet strategies in dairy cattle farms}

Ten risk management strategies were determined for farmers (Table 3). The most important risk management strategy with the highest mean was parasite control. This was followed by off-farm work, off-farm investment and on-farm measures. Hall et al (2003) reported that the most important risk management strategies were being a low-cost producer, off-farm investments and maintaining credit reserves. In another study, they were determined as take precautions for diseases, the lowest possible cost for production, and highly efficient animal breeds (Hayran \& Gül 2015). The ten items were distributed among three factors by factor analysis. KMO, Barlett's test and Cronbach's alpha values were determined as $0.783,611.72$ and 0.787 , respectively. These results supported to use of the factor analysis for risk strategies. Thus, three factors (from 1 to 3 ) were labeled as disease control, diversification, and financial management, respectively (Table 3). They explained $66.41 \%$ of total variance. Meuwissen et al (2001) explained that the most important risk management strategies were insurance, diversification, and certain income. In another study, they were determined as planning and insurance, off-farm income and diversification in production, and cost reduction (Hayran \& Gül 2015). Factor 1, disease control, had high loadings applying hygiene rules, use of veterinary services, parasite control and livestock insurance. There are positive relationship between Factor 1 and their risk management strategies. In farms, disinfection and cleaning applications that is made periodically have great importance on milk production. Thus, risks related to milk production can decrease as a result of obeying regularly to practices such as cleaning of feeding and milking equipments, and the use of veterinary services regularly to minimize risks relation to death and disease of animals. Although the pasture provides many benefits to farms, there are some diseases that affect adversely animals on pasture (Hawkins 1993). Hence, animals that are grazed on pasture are often exposed to high parasite, and so the effects of these diseases of animals are also felt economically. Thus, disease risk of animals can decrease as a result of using of regularly parasitic drugs and determining of effective parasite control programs. Livestock insurance is rather important in reducing the impact of the risks. Because, it can reduce the degree of risks by compensating the economic losses occurred depending on the risks such as accident, death, disease of animal. With livestock insurance, farmers can both protect against to other risks or disease their own animals and prevent to economic losses. Thus, it can be said that disease control factor have positive effects on animal diseases and hygiene practices in farms. Factor 2, financial management, had high loadings liquidity, producing at the lowest possible cost, record keeping in farm and livestock insurance. There are positive relationship between Factor 2 and their risk management strategies. Financial management is important in terms of improvement of productivity, increasing profitability, and fulfilling long-term goals. Thus, it can enhance to the profitability, the liquidity, and the solvency of farmers with financial management by decreasing negative financial consequences of risk sources (Aydın \& Günlü 2010). Liquidity have important role in the maintain to continuity of farms, and it affects to efficiency and profitability of farmers. Due to problems such as cash-flows, delays in payment, and falls in income, the maintaining adequate liquidity in farms protects to farmers from financial crisis occurred. Hence, farms need to have adequate liquidity. Also, the significant point in managing of working capital is ensured maintaining liquidity in day-to-day activity to assure its smooth running (Eljelly 2004). According to this result, it can be said that farms that have high liquidity in terms of working capital may have more low risks, and this situation is an important in terms of financial management of farms. Production with the lowest cost is essential to its profitability and sustainability of farms. Because, production cost should be at lowest possible level while obtaining a particular product by using input more than one in dairy cattle farms (Welch \& Welch 2016). Record keeping may provide an opportunity to farmers for evaluating both as technical and as economic of farms. Because, 
records kept help to farmers in selection of animals, in determination of disease status, and in evaluation of the amount of profit/loss each year. This practice is an important for sustainable livestock. Livestock insurance reduce to the degree of risks in farm by compensating the losses resulting from death, disease, and injury of animals. Therefore, farmers may show tendency to doing insurance in order to minimize to livestock losses. Thus, it can be said that livestock insurances is important in terms of financial management and losses of farms. Factor 3, diversification, had high loadings off-farm investment, off-farm work and on-farm measures. There are positive relationship between Factor 3 and their risk management strategies. Diversification aims combining activities of farms in order to reduce the variability of revenues. It is a selfdefense strategy used by farmers to preserve against various risks. However, many factors influence to the diversification in farmers' off-farm activities. Financial reasons is one of the factors affecting the diversification (Bradshaw 2004). As it is know, farmers face with some risk factors such as market and production. Therefore, off-farm investment, off-farm work and on-farm measures are important in decrease of the adverse impact of fluctuations on yield and/or price of these risks. Because, the variability in farm income is problem for farmers, and so it is essential to support risk management of farmers by diversification of assets, income, and activities (Bradshaw 2004). Hence, farmers may select to diversification to reduce variability in income. The aim of activities in relation with off-farm investment, off-farm work, and on-farm measures is closed with income provided from other activity areas of this deficiency when income provided from one activity area decrease. These results concerning risk management strategies show that they have positive influence on risks relation to dairy activity in research area. Also, it is neccessary to increase of the number of these precautions for improvement of farms.

Table 3- Mean and factor analysis results for risk management strategies

\begin{tabular}{lcrrrr}
\hline \multirow{2}{*}{ Risk management strategies } & Mean & & \multicolumn{3}{c}{ Important factors $^{c}$} \\
\cline { 4 - 6 } & $(n=302)$ & $S D^{b}$ & $F_{1}$ & \multicolumn{1}{c}{$F_{2}$} & $F_{3}$ \\
\hline Parasite control & 4.48 & 0.57 & 0.599 & 0.040 & 0.321 \\
Off-farm/non-farm work & 4.37 & 0.74 & 0.317 & -0.052 & 0.687 \\
Off-farm/non-farm investment & 4.27 & 0.73 & -0.171 & 0.081 & 0.851 \\
On-farm measures (diversification of product) & 4.00 & 0.76 & 0.180 & 0.242 & 0.610 \\
Use of veterinary services & 3.89 & 0.79 & 0.854 & 0.110 & 0.022 \\
Livestock insurance & 3.86 & 0.76 & 0.575 & 0.494 & 0.189 \\
Producing at the lowest possible cost & 3.83 & 0.76 & 0.282 & 0.806 & -0.013 \\
Record keeping in farm & 3.68 & 0.76 & 0.278 & 0.780 & 0.115 \\
Applying hygiene rules & 3.65 & 0.87 & 0.880 & 0.168 & -0.005 \\
Liquidity (keep cash on hand) & 3.58 & 0.85 & -0.158 & 0.866 & 0.140 \\
\hline
\end{tabular}

a,b, mean and standard deviation (SD) (1, not important; 5, very important); ${ }^{\mathrm{c}}$, factors 1 to 3 are labelled as $\mathrm{F}_{1}$, disease control; $\mathrm{F}_{2}$, diversification; $F_{3}$, financial management; factor loadings for value greater than 0.4 are in bold

\section{Conclusions}

This study aimed to determine farmers' risks and their strategies in dairy cattle farms in Çanakkale province and its districts (Biga and Çan). The results of this study shows that the most important risk resource of farmers is arise from lack of credit availability. As a solution to the lack of credit availability, it should be provided to ease of repayment in credit use and to inceasing opportunities to loan use with low interest rate of farmers in research area. One of the risk sources is inadequacy of artificial insemination use by farmers. Therefore, it should be provided to increasing of the number of farmers that use artificial 
insemination and of their success in implementing artificial insemination in order to decrease production losses in farms. Another risk source is increase in debt amount of farms. The adverse effect of this risk can decrease by diversification of product and increasing of quantity of off-farm income. Parasite control was determined as the most important risk management strategy in farms. Another important risk management strategies are also off-farm work, off-farm investment and onfarm measures. These management strategies can be affective in decreasing of the adverse impacts of fluctuations on yield and/or price in production. All these findings show that farmers engage in cope with various risk sources in order to secure livelihood and continue to farm activities and thus it is important of risk management strategies that will be determined according to farm conditions. Thus, the results of this research may provide useful information for farmers, researchers and policy makers, and to helpful in cope with farmers' risks. Also, these information can also be important for institutions and services regarding livestock.

\section{References}

Ağır H B, Saner G \& Adanacıoğlu H (2015). Risk sources encountered by farmers in the open field production of strawberry and risk management strategies: a case of Menemen-Emiralem district of İzmir. Journal of Agricultural Sciences 21(1): 13-25

Akçaöz H, Kizilay H \& Ozcatalbas O (2009). Risk management strategies in dairy farming a case of study in Turkey. Journal of Animal and Veterinary Advances 8(5): 949-958

Aydın İ \& Günlü A (2010). Development of a software program for storing and evaluating technical and financial data in livestock breeding enterprises. Journal of Turkish Veterinary Medical Society 80(4): 21-30

Bishu K G, Reilly S O, Lahiff E \& Steiner B (2016). Cattle farmers' perceptions of riskand risk management strategies: evidence from Northern Ethiopia. Journal of Risk Research 19(1): 1-20

Bradshaw B (2004). Questioning crop diversification as a response to agricultural deregulation in Saskatchewan, Canada. Journal of Rural Studies 20(1): 35-48
Bosch D J \& Johnson C J (1992). An evaluation of risk management strategies for dairy farms. Southern Journal of Agricultural Economics 24(2): 173-182

Çukur F, Saner G, Çukur T \& Dayan V (2011). Risk and risk strategies on olive farming in milas district of Muğla province, Turkey. Journal of Food, Agriculture \& Environment 9(1): 190-194

Eljelly A M A (2004). Liquidity-profitability tradeoff: an empirical investigation in an emerging market. International Journal of Commerce and Management 14(2): 48-61

Ferraz J B S, Eler J P \& Rezende F M (2012). Impact of using artificial insemination on the multiplication of high genetic merit beef cattle in Brazil. Animal Reproduction Science 9(3): 133-138

Flaten O, Lien G, Koesling M, Valle P S \& Ebbesvik M (2005). Comparing risk perceptions and risk management in organic and conventional dairy farming: empirical results from Norway. Livestock Production Science 95(1-2): 11-25

Hair J F, Andersen R E, Tatham R L \& Black W C (1995). Multivariate Data Analysis. Macmillan Publishing Company, New York

Hall D C, Knight T O, Coble K H, Baquet A E \& Patrick G F (2003). Analysis of beef producers' risk management perceptions and desire for further risk management education. Review of Agricultural Economics 25(20): 430-448

Hawkins J A (1993). Economic benefits of parasite control in cattle. Veterinary Parasitology Veterinary Parasitology 46(1-4): 159-173

Hayran S \& Gül A (2015). Risk perception and management strategies in dairy farming: a case of adana province of Turkey. Turkish Journal of Agriculture Food Science and Technology 3(12): 952961

Hazneci E \& Ceyhan V (2011). Risk analysis of dairy farms in Merzifon district of Amasya province. Mediterranean Agricultural Sciences 24(2): 109-114

Huirne R B M, Meuwissen M P M, Hardaker J B \& Anderson J R (2000). Risk and risk $m$ a $n$ a g e $m$ e $n t$ in agriculture: an overview and empiricial results. International Journal of Risk Assessment and Management 1(1-2): 125-136

Meuwissen M P M, Huirne R B M \& Hardaker J B (2001). Risk and risk management: an empirical analysis of dutch livestock farmers. Livestock Production Science 69(1): 43-53 
Noordhuizen J P T M \& Cannas da S (2014). HACCPbased quality risk management approach to udder health problems on dairy farms. Irish Veterinary Journal 62(4): 21-25

Schaper C, Lassen B \& Theuvsen L (2009). Risk management in milk production: a study in five european countries. In: Proceedings of the $113^{\text {th }}$ EAAE Seminar 'A Resilient European Food Industry and Food Chain in A Challenging World”, 3-6 September, Chania, Crete, Greece, pp: 1-16

SPSS (2008). SPSS Statistics Base 17.0 for Windows User's Guide SPSS Inc, Chicago

Thornton P K (2010). Livestock production: recent trends, future prospects. Philosophical Transactions of the Royal Society 365(1554): 2853-2867

Turan N \& Altuner F (2014). The roughage production potential, problems and suggestions in Van province. Turkish Journal of Agricultural Research 1(1): 91-97
Turkstat (2016). Statistical indicators. Turkish statistical institute. Retrieved in December, 4, 2016 from http:// www.turkstat.gov.tr/

Özsayın D \& Çetin B (2004). Risk and risk management perceptions in the dairy farms with livestock insurance. In: Proceedings of the $4^{\text {th }}$ National Congress of Agricultural Economics, 16-18 September, Tokat, pp: 197-200

Welch P J \& Welch G F (2016). Economics: Theory and Practice. John Wiley and Sons Inc, USA

Yamane T (1967). Elementary Sampling Theory. PrenticeHall Inc, New Jersey

Zhou H, Nanseki T \& Shigeyoshi T (2012). Dairy farmers' risk perception and risk management in China evidence from Hebei province and inner Mongolia. Agricultural Information Research 21(2): 20-27 